\title{
ANALISIS ELASTISITAS PERMINTAAN KONSUMEN RUMAH TANGGA TERHADAP TELUR AYAM RAS DI KOTA BANDA ACEH
}

\author{
(Analysis of elasticity of demand for eggs in banda aceh city)
}

\author{
M. Luthfi Syirah Murandawi ${ }^{1}$, Fajri ${ }^{1}$, Mustafa ${ }^{1 *}$ \\ ${ }^{1}$ Program Studi Agribisnis, Fakultas Pertanian, Universitas Syiah Kuala
}

\begin{abstract}
Abstrak. Permintaan Telur Ayam ras di kota banda aceh dipengaruhi oleh harga telur ayam ras, harga ikan, harga minyak goreng, pendapatan dan jumlah tanggungan. Penelitian ini bertujuan untuk melihat permintaan telur ayam dipengaruhhi oleh harga telur ayam ras, harga ikan, harga minyak goreng, pendapatan dan jumlah tanggungan serta untuk melihat elastisitas harga, elastisitas silang dan elastisitas pendapatan. Penarikan sample diperoleh dengan metode propotional stratified random sampling di Kota Banda Aceh dimana untuk stata pendapatan tinggi 25 , menengah 65 dan rendah 33 sampel . Teknik yang dilalukan pada peneitian ini dengan Regresi Linear Berganda. Hasil penelitian ini menunjukan harga telur ayam ras, harga ikan, harga minyak goreng, pendapatan dan jumlah tanggungan berpengaruh nyata secara serempak, dan elastisitas harga nya elastis untuk menengah dan rendah, sedangkan tinggi inelastis, elastisitas silang subtitusi untuk ikan dan komplementer untuk minyak goreng, dan untuk elastisitas pendapatan nya telur ayam ras termasuk ke barang inferior.
\end{abstract}

Kata Kunci : Permintaan Telur Ayam ras, harga telur ayam ras, harga ikan, harga minyak goreng, pendapatan, jumlah tanggungan, elastisitas harga, elastisitas silang, dan elastisitas pendapatan.

\begin{abstract}
Demand for Chicken Eggs in the city of banda aceh is influenced by the price of eggs, the price of the egg, the price of cooking oil, the income and the number of dependents. This study aims to see the demand for chicken eggs influenced by the price of eggs, the price of the village egg, the price of cooking oil, the income and the number of dependents and to see the price elasticity, cross elasticity and income elasticity. Sampling was obtained by multi stage cluster random sampling method in Kota Banda Aceh with a sample of 46 family heads. Techniques performed on this study with Multiple Linear Regression. The results of this study indicate the price of eggs, the price of eggs, the price of cooking oil, the income and the number of dependents have a significant effect simultaneously, while partially only the price of eggs, the price of cooking oil and the number of dependents that have real effect, and elasticity of its price elastic, cross-substitution elasticity for chicken eggs and complementary for cooking oil, and for his income elasticity of chicken eggs belonging to normal goods.
\end{abstract}

Keywords : Permintaan Telur Ayam ras, harga telur ayam ras, harga ikan, harga minyak goreng, pendapatan, jumlah tanggungan, elastisitas harga, elastisitas silang, dan elastisitas pendapatan.

\section{PENDAHULUAN}

Telur ayam merupakan sumber makanan yang bernilai gizi tinggi. Semua golongan masyarakat mengkonsumsi telur ayam untuk memenuhi kebutuhan protein hewaninya selain dari daging. Ini semua disebabkan karna telur merupakan salah satu makanan yang mudah diperoleh, mudah cara pengolahannya serta harganya yang tidak mahal. Oleh karena itu telur merupakan jenis bahan makanan yang selalu dibutuhkan dan dikonsumsi secara luas oleh masyarakat dalam memnuhi kebutuhan sehari - hari. 


\begin{tabular}{cccccc}
\hline Jenis Telur & $\begin{array}{c}2012 \\
\text { (butir) }\end{array}$ & $\begin{array}{c}2013 \\
\text { (butir) }\end{array}$ & $\begin{array}{c}\text { Tahun } \\
2014 \\
\text { (butir) }\end{array}$ & $\begin{array}{c}2015 \\
\text { (butir) }\end{array}$ & $\begin{array}{c}2016 \\
\text { (butir) }\end{array}$ \\
\hline Ayam Ras & 361.350 .000 & 361.353 .480 & 722.700 .000 & 735.200 .000 & 771.960 .000 \\
$\begin{array}{c}\text { Ayam Buras } \\
\text { (Kampung) }\end{array}$ & 154.338 & 271.100 & 36.143 .368 & 8.628 & 11.710 \\
\hline Jumlah & $\mathbf{3 6 1 . 5 0 4 . 3 3 8}$ & $\mathbf{3 6 1 . 6 2 4 . 5 8 0}$ & $\mathbf{7 5 8 . 8 4 3 . 3 6 8}$ & $\mathbf{7 3 5 . 2 0 8 . 6 2 8}$ & $\mathbf{7 7 1 . 9 7 1 . 7 1 0}$ \\
\hline Sumbr:
\end{tabular}

Sumber:BPS Kota Banda Aceh dalam angka 2017

Sukirno (2005) juga mengungkapkan bahwa ada beberapa faktor yang mempengaruhi permintaan akan suatu barang selain harga barang itu sendiri. Faktor-faktor tersebut antara lain harga barang lain, pendapatan pembeli (konsumen), distribusi pendapatan, cita rasa masyarakat, jumlah penduduk, dan ekspektasi tentang masa depan. Pracoyo (2006) juga mengungkapkan ada beberapa faktor yang mempengaruhi permintaan itu sendiri yaitu antara lain harga barang itu sendiri, pendapatan, dan jumlah tanggungan.Selanjutnya Daniel ( 2004 ) juga berpendapat bahwasanya faktor yang mampu mempengaruhi permintaan terhadap suatu barang yaitu harga barang yang bersangkutan, harga barang lain (subtitusi dan komplementer ), dan pendapatan.

\begin{tabular}{lc}
\hline \multicolumn{1}{c}{ Bulan } & Harga $(\mathrm{Rp} / \mathrm{butir})$ \\
\hline Januari & 1.464 \\
Februari & 1.378 \\
Maret & 1.378 \\
April & 1.327 \\
Mei & 1.367 \\
Juni & 1.367 \\
Juli & 1.381 \\
Agustus & 1.424 \\
September & 1.422 \\
Oktober & 1.408 \\
November & 1.340 \\
Desember & 1.361 \\
\hline Rata - Rata & $\mathbf{1 . 3 8 5}$ \\
\hline Sumber : BPS Kota Banda Aceh Dalam Angka Tahun 2017.
\end{tabular}

Sumber : BPS Kota Banda Aceh Dalam Angka Tahun 2017.

Elastisitas permintaan merupakan suatu ukuran kuantitatif yang menunjukkan besarnya pengaruh perubahan harga atau faktor-faktor lainnya terhadap perubahan permintaan suatu komoditas. Secara umum elastisitas permintaan dapat dibedakan menjadi elastisitas permintaan terhadap harga (price elasticity of demand), elastisitas permintaan terhadap pendapatan (income elasticity of demand), dan elastisitas permintaan silang (cross price elasticity of demand). Elastisitas permintaan terhadap harga, mengukur seberapa besar perubahan jumlah komoditas yang diminta apabila harganya berubah. Jadi elastisitas permintaan terhadap harga adalah ukuran kepekaan perubahan jumlah komoditas yang diminta terhadap perubahan harga komoditas tersebut dengan asumsi ceteris paribus. Nilai elastisitas permintaan terhadap harga merupakan asil bagi antara persentase perubahan harga. Nilai yang diperoleh tersebut merupakan suatu besaran yang menggambarkan sampai berapa besarkah perubahan jumlah komoditas yang diminta apabila dibandingkan dengan perubahan harga (Sugiarto, 2005). Berdasarkan latar belakang diatas, maka rumusan masalah penelitian ini yaitu apakah harga telur ayam ras, harga barang subtitusi, harga barang komplementer, dan jumlah tanggungan rumah

Analisis Elastisitas Permintaan Konsumen Rumah Tangga Terhadap Telur Ayam Ras Di Kota Banda 55 Aceh (M. Luthfi, Mustafa, Fajri)

Jurnal Ilmiah Mahasiswa Pertanian Unsyiah, Vol.3, No.3, Agustus 2018:54-65 
tangga mempengaruhi permintaan rumah tangga terhadap telur ayam ras di kota Banda Aceh serta bagaimanakah elastisitas permintaan telur ayam ras dikota Banda Aceh jika diliha dari beberapa strata berdasarkan pendapatannya ?. Penelitian ini bertujuan untuk mengetahui harga telur ayam ras, harga barang subtitusi, harga barang komplementer, pendapatan dan jumlah tanggungan rumah tangga mempengaruhi permintaan telur ayam ras di kota Banda Aceh serta melihat bagaimanakah elastisitas permintaan telur ayam ras yang dilihat dari beberapa strata berdasarkan pendapatannya.

\section{Lokasi dan Waktu Penelitian}

\section{METODE PENELITIAN}

Lokasi penelitian ini dilakukan di kota Banda Aceh, penentuan lokasi penelitian ini di lakukan secara sengaja (purposive sampling) dengan pertimbangan bahwa Kota Banda Aceh yaitu ibu kota dari Provinsi Aceh, dimana menjadi pusat kegiatan ekonomi, politik, sosial dan budaya. Sedankan Waktu penelitian ini dilakukan pada bulan Maret 2018.

\section{Objek dan Ruang Lingkup Penelitian}

Objek dalam penelitian ini yaitu rumah tangga yang ada di kota Banda Aceh. Sedangkan ruang lingkup dalam penelitian ini terbatas pada faktor - faktor yang mempengaruhi permintaan telur ayam ras dan elastisitas permintaan telur ayam ras. Sedangkan faktor faktor yang mempengaruhinya meliputi harga telur ayam ras, harga barang subtitusi, harga barang kompementer, pendapatan dan jumlah tanggungan rumah tangga. Sedangkan elastistas permintaan meliputi elastisitas harga, elastisitas silang dan elastisitas pendapatan.

\section{Sumber dan Metode Pengumpulan Data}

Data yang digunakan dalam penelitian ini adalah data primer dan data sekunder. Data primer adalah data yang diperoleh melalui wawancara dengan kepala eluarga rumah tangga secara langsung dengan menggunakan kuisioner sedangkan data sekunder diperoleh dari instansi terkait dan studi kepustakaan. Data tersebut nantinya digunakan dalam pengujian dan analisa dalam penelitian ini.

\section{Faktor-Faktor Yang Mempengaruhi Permintaan Teluar Ayam Ras diKota Banda} Aceh

Model analisis yang digunakan dalam pengujian hipotesis adalah: "Regresi Linier Berganda", untuk menganalisis pengaruh beberapa faktor terhadap permintaan Telur Ayam Ras di Kota Bnada Aceh. Penggunaan model ini menggunakan fungsi cobb douglas, yaitu suatu fungsi yang melibatkan dua atau lebih variabel yang dipengaruhi (y) dan variabel lain yang mempengaruhi $(\mathrm{X})$, sehingga bila fungsi cobb douglas tersebut dinyatakan oleh y dan $\mathrm{x}$ maka :

$\log y=\log a+b_{1} \log X_{1}+b_{2} \log X_{2}+b_{3} \log X_{3}+b_{4} \log X_{4}+b_{5} \log X_{5}+e_{i}$

Dimana:

$$
\begin{array}{ll}
\mathrm{y} & =\text { Variabel yang dijelaskan (Permintaan telur ayam ras }) \\
\mathrm{X}_{1} & =\text { Harga Telur Ayam Ras }(\mathrm{Rp} / \text { Butir }) \\
\mathrm{X}_{2} & =\text { Harga Ikan }(\mathrm{Rp} / \mathrm{kg}) \\
\mathrm{X}_{3} & =\text { Harga Minyak Goreng }(\mathrm{Rp} / \mathrm{kg}) \\
\mathrm{X}_{4} & =\text { Pendapatan (Rp/Bulan) }
\end{array}
$$

Analisis Elastisitas Permintaan Konsumen Rumah Tangga Terhadap Telur Ayam Ras Di Kota Banda 56 Aceh (M. Luthfi, Mustafa, Fajri)

Jurnal Ilmiah Mahasiswa Pertanian Unsyiah, Vol.3, No.3, Agustus 2018:54-65 


$$
\begin{array}{ll}
\mathrm{X}_{5} & =\text { Jumlah Tanggungan (Jiwa) } \\
\mathrm{a} & =\text { Konstana } \\
\mathrm{e}_{\mathrm{i}} & =\text { Error } \\
\text { bi....... }_{5} & =\text { Koefesien Regresi. }
\end{array}
$$

\section{a. Uji-f}

Untuk mengetahui pengaruh secara serempak antar variabel bebas $\left(\mathrm{X}_{1}, \mathrm{X}_{2}, \mathrm{X}_{3}, \mathrm{X}_{4}, \mathrm{X}_{5}\right)$ terhadap variabel terikat $(Y)$ pada taraf nyata $(\alpha=0.05)$ Diuji dengan menggunakan uji $F$ dengan menggunakan rumus sebagai berikut:

$$
\mathrm{F}_{\text {cari }}=\frac{R^{2} / \mathrm{k}}{\left(1-R^{2}\right) /(n-k-1)} \quad(\text { Sudjana, 2002) }
$$

Keterangan:

$\mathrm{R}^{2}=$ Koefisien determinasi

$\mathrm{K} \quad$ = jumlah variabel bebas

$\mathrm{n} \quad=$ jumlah sampel

Hipotesis:

Ho = Harga Telur Ayam Ras, Harga Ikan, Harga Minyak Goreng, Pendapatan dan Jumlah Tanggungan secara serempak berpengaruh nyata terhadap Permintaan Telur Ayam Ras di Kota Banda Aceh

Ha = Harga Telur Ayam Ras, Harga Ikan, Harga Minyak Goreng, Pendapatan dan Jumlah Tanggungan secara serempak tidak berpengaruh nyata terhadap Permintaan Telur Ayam Ras di Kota Banda Aceh

\section{Uji-t}

Untuk mengetahui pengaruh secara parsial, yaitu untuk menguji keeratan hubungan antara sebagian dan sejumlah variabel apabila variabel dengan variabel yang lain dianggap tetap. Diuji dengan menggunakan uji " $t$ " dengan menggunakan rumus:

$$
\mathrm{t}_{\text {cari }}=\frac{\left|a_{i}\right|}{S E_{n i}} \quad(\text { Sudjana,2002) }
$$

keterangan:

$\mathrm{a}_{\mathrm{i}} \quad=$ Koefisien regresi ke- $\mathrm{i}$

$\mathrm{SE}_{\mathrm{ni}}=$ Standar Error ke-1

\section{Hipotesis:}

Ho = Harga Telur Ayam Ras, Harga Ikan, Harga Minyak Goreng, Pendapatan dan Jumlah Tanggungan secaa parsial berpengaruh nyata terhadap Permintaan Telur Ayam Ras di Kota Banda Aceh

Analisis Elastisitas Permintaan Konsumen Rumah Tangga Terhadap Telur Ayam Ras Di Kota Banda 57 Aceh (M. Luthfi, Mustafa, Fajri)

Jurnal Ilmiah Mahasiswa Pertanian Unsyiah, Vol.3, No.3, Agustus 2018:54-65 
Ha = Harga Telur Ayam Ras, Harga Ikan, Harga Minyak Goreng, Pendapatan dan Jumlah Tanggungan secara parsial tidak berpengaruh nyata terhadap Permintaan Telur Ayam Ras di Kota Banda Aceh

\section{Uji Koefisien Determinasi $\left(\mathbf{R}^{\mathbf{2}}\right)$}

Koefisien determinasi menunjukkan seberapa besar persentase variasi dalam variabel dependen yang dapat dijelaskan dalam variabel independen. Nilai R square terletak antara 0 dan 1 . Jika $\mathrm{R}^{2}$ semakin mendekati 1 maka semakin besar variasi dalam variabel independen. Hal ini berarti semakin tepat garis regresi tersebut mewakili hasil penelitian yang sebenarnya. Koefisien determinasi pada intinya mengukur seberapa jauh kemampuan model dalam menerangkanvariabel bebas $(\mathrm{X})$ terhadap variabel terikat $(\mathrm{Y})$. Untuk menguji koefisien determinasi $\mathrm{R}^{2}$ maka dapat digunakan rumus sebagi berikut:

$$
\mathrm{R}^{2}=\frac{j k_{(r e g)}}{\Sigma y i^{2}}
$$
(Sudjana, 2002)

Dimana :

$j k_{(r e g)}=$ Jumlah kuadrat regresi

$\Sigma y i^{2}=$ Jumlah kuadrat total

Untuk menguji nilai elastisitas dapat langsung digunakan hasil dari transformasi regresi linier berganda yaitu sebesar bi (Prince, 2016). Sehingga dapat diketahui nilai elastisitas sebagai berikut:

\begin{tabular}{|c|c|c|c|c|}
\hline No. & Elastisitas & Rumus & Kriteria & Keterangan \\
\hline 1 & Harga & $\mathrm{E}_{\mathrm{p}}=\frac{\Delta Q}{\Delta P_{x}} \mathrm{x} \frac{P_{x}}{Q}$ & $\begin{array}{l}E_{p}<1 \text {, inelastis } \\
E_{p}>1 \text {, elastis } \\
E_{p}=1 \text {, elastis uniter } \\
E_{p} \infty \text {, elastisitas sempurna } \\
E_{p}=0 \text {, inelastis sempurna }\end{array}$ & $\begin{array}{l}\Delta_{\mathrm{Q}}=\text { perubahan jumlah } \\
\text { barang yang diminta } \\
\mathrm{Q}=\text { jumlah barang yang } \\
\text { diminta } \\
\mathrm{P}_{\mathrm{X}}=\text { harga barang } \\
\text { tersebut }\end{array}$ \\
\hline 2 & Silang & $\mathrm{E}_{\mathrm{s}}=\frac{\Delta Q}{\Delta P_{y}} \times \frac{P_{y}}{Q}$ & $\begin{array}{l}E_{\mathrm{s}}=+(\text { barang subtitusi }) \\
E_{\mathrm{s}}=0 \text { (barang normal) } \\
E_{\mathrm{s}}=-(\text { barang komplementer })\end{array}$ & $\begin{array}{l}\Delta \mathrm{P}=\text { perubahan harga } \\
\text { barang } \\
\Delta \mathrm{P}_{\mathrm{y}}=\text { perubahan harga } \\
\text { barang lain }\end{array}$ \\
\hline 3. & Pendapatan & $\mathrm{E}_{\mathrm{i}}=\frac{\Delta Q}{\Delta i} \times \frac{i}{Q}$ & $\begin{array}{l}E_{\mathrm{i}} \leq 0 \text {, barang inferior } \\
0<\mathrm{E}_{\mathrm{i}}<1 \text {, barang normal } \\
\mathrm{E}_{\mathrm{i}}>1 \text {, barang mewah }\end{array}$ & $\begin{array}{l}\mathrm{P}_{\mathrm{y}}=\text { harga barang lain } \\
\Delta \mathrm{i}=\text { perubahan } \\
\text { pendapatan } \\
\mathrm{I}=\text { pendapatan }\end{array}$ \\
\hline
\end{tabular}

Sumber: (Sukirno, 2003)

\section{HASIL DAN PEMBAHASAN}

Analisis Faktor-Faktor Yang Mempengaruhi Permintann Telur Ayam Ras di Kota Banda Aceh.

\section{Strata Pendapatan Tinggi}

Pada Strata pendapatan tinggi secara serempak harga telur ayam ras, harga ikan, harga minyak, pendapatan dan jumlah tanggungan mempengaruhi nyata terhadap permintaan telur ayam ras di Kota Banda Aceh, didapatkan nilai $F_{\text {hitung }} 8,794$ sedangkan $f_{\text {tabel }} 2,74$ jadi kesimpulannya diterima $\mathrm{H}_{\mathrm{a}}$.Sedangkan secara parsial yang mempengaruhi secara

Analisis Elastisitas Permintaan Konsumen Rumah Tangga Terhadap Telur Ayam Ras Di Kota Banda 58 Aceh (M. Luthfi, Mustafa, Fajri)

Jurnal Ilmiah Mahasiswa Pertanian Unsyiah, Vol.3, No.3, Agustus 2018:54-65 
signifkan hanya jumlah tanggungan yang bepengaruh secara nyata terhadap permintaan telur ayam ras di kota Banda Aceh.

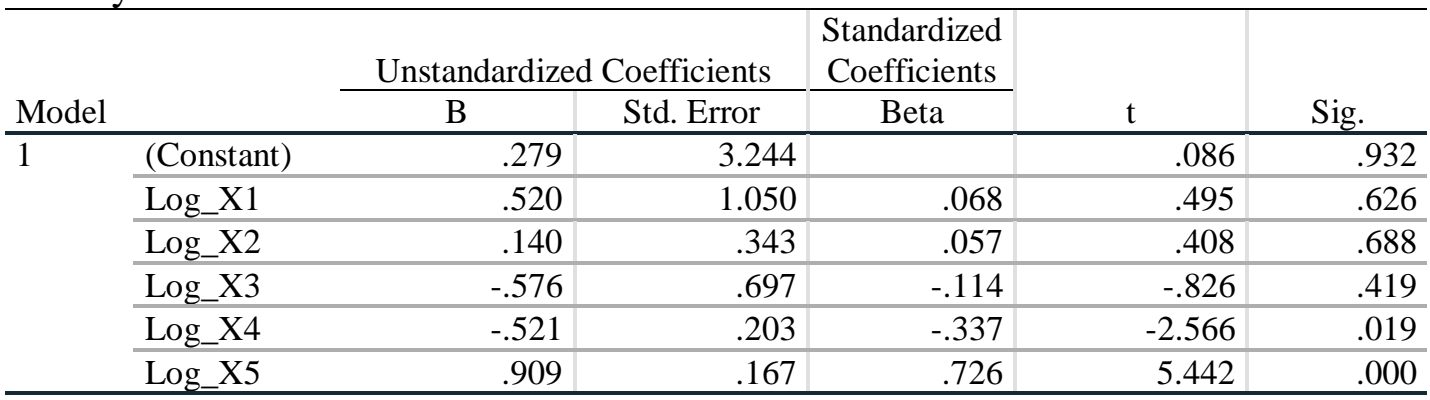

Sumber: Data primer, diolah 2018.

$\log \mathrm{y}=0,279+0,520 \mathrm{X}_{1}+0,140 \mathrm{X}_{2}-0,576 \mathrm{X}_{3}-0,521 \mathrm{X}_{4}+0,909 \mathrm{X}_{5}$

Nilai koefisien regresi harga telur ayam ras $\left(\mathrm{X}_{1}\right)$ sebesar 0,520 , artinya setiap peningkatan harga telur ayam ras sebesar Rp 1/butir maka akan meningkatkan permintaan telur ayam ras sebanyak 0,520 butir..Nilai koefisien regresi harga ikan $\left(\mathrm{X}_{2}\right)$ 0,140 artinya setiap peningkatan harga ikan sebesar Rp 1/butir maka akan meningkatkan permintaan telur ayam ras sebanyak 0,140 butir.Nilai koefisien regresi harga minyak goreng $\left(\mathrm{X}_{3}\right)$ didapatkan nilai sebesar -0.576 , artinya setiap penambahan harga minyak goreng $\mathrm{Rp} 1 / \mathrm{Kg}$ maka akan menurunkan permintaan telur ayam ras sebesar 0,576 butir. Nilai koefisien regresi pendapatan $\left(\mathrm{X}_{4}\right)$ sebesar $-0,521$, artinya setiap pendapatan bertambah sebesar $\mathrm{Rp}$ 1 maka akan menurunkan permintaan telur ayam ras sebanyak 0,521 butir..Nilai koefisien regresi jumlah tanggungan $\left(\mathrm{X}_{5}\right)$ adalah 0,909 , artinya setiap peningkatan jumlah tanggungan 1 jiwa maka akan menaikkan permintaan telur ayam ras sebanyak 0,909 butir.

Uji t dilakukan untuk melihat pengaruh variabel independen (bebas) secara individu atau parsial terhadap variabel dependen (terikat) dengan menganggap variabel lainnya konstan. Bila $t_{\text {hitung }}>t_{\text {tabel }}$ dengan signifikansi sebesar 5\% maka dapat disimpulkan bahwa secara individu variabel independen berpengaruh signifikan terhadap variabel dependen. Jika $t_{\text {hitung }}<\mathrm{t}_{\text {tabel }}$ dengan tingkat signifikansi 5\% maka dapat disimpulkan variabel independen tidak berpengaruh terhadap variabel dependen. Sementara nilai $t_{\text {tabel }}$ pada tingkat kesalahan 5\%, jumlah sampel variabel (terikat dan bebas) sebanyak 6 dan jumlah sampel 25 adalah 1,72913. Adapun penjelasan mengenai pengaruh masing-masing variabel bebas terhadap permintaan telur ayam ras di Kota Banda Aceh.

Dari tabel output SPSS dapat dilihat bahwa variabel secara parsial yang berpengaruh nyata (signifikan) terhadap permintaan telur ayam ras dikota Banda Aceh untuk strata pendapatan tinggi yaitu pendapatan (X4) dan jumlah tanggungan (X5). Dimana pendapatan (X4) thitung > tabel yaitu 2,566 > 1,72913 dan taraf signifikan nya 0,019< 0,05 . Akan tetapi pengaruh dari pendapatan (X4) ini negative dimana kenaikan nya akan menurunkan permintaan telur ayam ras. Dan untuk jumlah tanggungan (X5) ttabel $>$ thitung yaitu 5,442>1,72913 dan taraf signifikan nya $0,000<0,05$. Sedangkan varibael lainnya yaitu harga telur ayam ras (X1), harga ikan (X2) dan harga minyak goreng (X3) secara parsial tidak berpengaruh nyata terhadap permitaan telur ayam ras dikota Banda Aceh untuk strata pendapata tinggi. Dimana ttabel < thitung dan taraf signifikan nya lebih besar dari 0,05 .

Analisis Elastisitas Permintaan Konsumen Rumah Tangga Terhadap Telur Ayam Ras Di Kota Banda 59 Aceh (M. Luthfi, Mustafa, Fajri)

Jurnal Ilmiah Mahasiswa Pertanian Unsyiah, Vol.3, No.3, Agustus 2018:54-65 


\begin{tabular}{lccc}
\hline Variabel & \multicolumn{3}{c}{ Nilai Elastisitas } \\
\cline { 2 - 4 } & Harga & Silang & Pendapatan \\
\hline Harga Telur Ayam Ras (X1) & 0,520 & & \\
Harga Ikan (X2) & & 0,140 & \\
Harga minyak goreng (X3) & & $-0,576$ & \\
Pendapatan (X4) & & $-0,521$ \\
\hline
\end{tabular}

Sumber: Data Primer, 2018 (diolah)

Dari tabel diatas dapat dilihat bahwa nilai elastisitas permintaan harga telur ayam ras di Kota Banda Aceh untuk strata pendapatan tinggi adalah 0,520.Sehingga dapat disimpulkan bahwa elastisitas permintaan harga nya tidak elastis (inelastis), karena Ep < 1. Sedangkan nilai untuk harga ikan menunjukkan bahwa ikan menjadi barang subtitusi terhadap telur ayam ras, yaitu nilainya sama dengan positif (+) dan nilai untuk harga minyak goreng menunjukkan bahwa minyak goreng merupakan barang komplementer terhadap telur ayam yaitu nilainya sama dengan negaif (-). Selanjutnya untuk nilai elastisitas pendapatan juga dapat disimpulkan Telur ayam ras merupakan inferior, karena nilai dari pendapatan lebih kecil dari 0 , dan nilai untuk strata pendapatan tinggi yaitu $0,521<0$.

\section{Strata Pendapatan Menengah}

Pada Strata pendapatan menengah secara serempak harga telur ayam ras, harga ikan, harga minyak, pendapatan dan jumlah tanggungan mempengaruhi nyata terhadap permintaan telur ayam ras di Kota Banda Aceh, didapatkan nilai $F_{\text {hitung }} 33,227$ sedangkan $\mathrm{f}_{\text {tabel }}$ 2,37 jadi kesimpulannya diterima $\mathrm{H}_{\mathrm{a}}$.Sedangkan secara parsial yang mempengaruhi secara signifkan hanya harga telur ayam ras, harga ikan dan jumlah tanggungan yang bepengaruh secara nyata terhadap permintaan telur ayam ras di kota Banda Aceh.

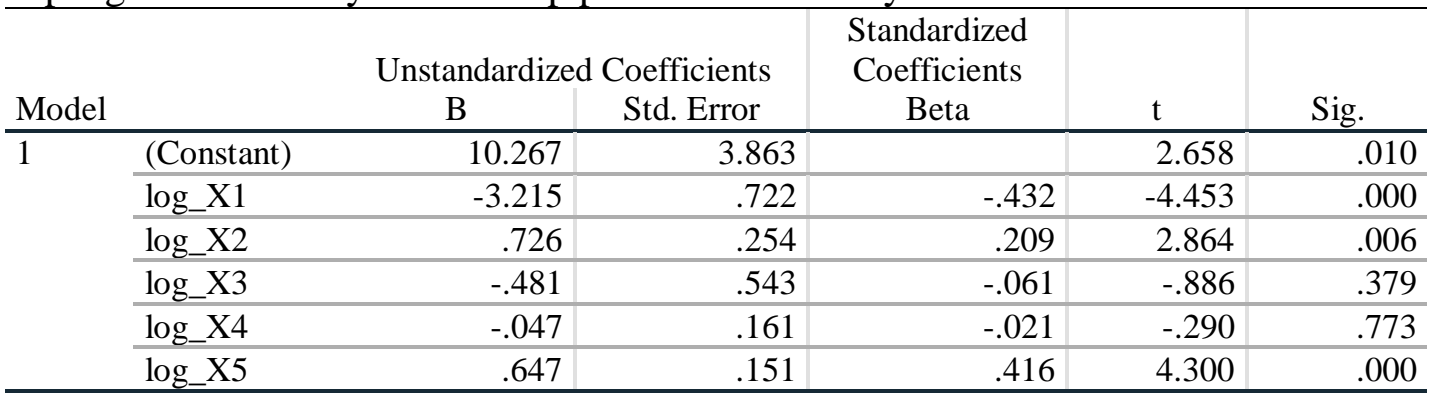

Sumber: Data primer, diolah 2018.

$\log \mathrm{y}=10,267-3,215 \mathrm{X}_{1}+0,726 \mathrm{X}_{2}-0,481 \mathrm{X}_{3}-0,047 \mathrm{X}_{4}+0,647 \mathrm{X}_{5}$

Nilai koefisien regresi harga telur ayam ras $\left(\mathrm{X}_{1}\right)$ sebesar $-3,215$, artinya setiap peningkatan harga telur ayam ras sebesar Rp 1/butir maka akan menurunkan permintaan telur ayam ras sebanyak 3,215 butir..Nilai koefisien regresi harga ikan $\left(\mathrm{X}_{2}\right) 0,726$ artinya setiap peningkatan harga ikan sebesar Rp 1/butir maka akan meningkatkan permintaan telur ayam ras sebanyak 0,726 butir.Nilai koefisien regresi harga minyak goreng $\left(\mathrm{X}_{3}\right)$ didapatkan nilai sebesar -0.481 , artinya setiap penambahan harga minyak goreng $\mathrm{Rp} 1 / \mathrm{Kg}$ maka akan menurunkan permintaan telur ayam ras sebesar 0,481 butir. Nilai koefisien regresi pendapatan $\left(\mathrm{X}_{4}\right)$ sebesar $-0,047$, artinya setiap pendapatan bertambah sebesar Rp 1 maka akan menurunkan permintaan telur ayam ras sebanyak 0,521 butir. Nilai koefisien regresi jumlah tanggungan $\left(\mathrm{X}_{5}\right)$ adalah 0,647 , artinya setiap peningkatan jumlah

Analisis Elastisitas Permintaan Konsumen Rumah Tangga Terhadap Telur Ayam Ras Di Kota Banda 60 Aceh (M. Luthfi, Mustafa, Fajri)

Jurnal Ilmiah Mahasiswa Pertanian Unsyiah, Vol.3, No.3, Agustus 2018:54-65 
tanggungan 1 jiwa maka akan menaikkan permintaan telur ayam ras sebanyak 0,647 butir.

Uji t dilakukan untuk melihat pengaruh variabel independen (bebas) secara individu atau parsial terhadap variabel dependen (terikat) dengan menganggap variabel lainnya konstan. Bila $t_{\text {hitung }}>t_{\text {tabel }}$ dengan signifikansi sebesar $5 \%$ maka dapat disimpulkan bahwa secara individu variabel independen berpengaruh signifikan terhadap variabel dependen. Jika $t_{\text {hitung }}<\mathrm{t}_{\text {tabel }}$ dengan tingkat signifikansi 5\% maka dapat disimpulkan variabel independen tidak berpengaruh terhadap variabel dependen. Sementara nilai $t_{\text {tabel }}$ pada tingkat kesalahan 5\%, jumlah sampel variabel (terikat dan bebas) sebanyak 6 dan jumlah sampel 65 adalah 1.67109 dan taraf signifikan nya lebih kecil dari 0,05.Sehingga di dapatkan variabel - variabel yang berpengaruh secara signifikan yang dilihat secara parsial dan yang tidak signiifikan secara parsial..

Dari tabel output SPSS dapat dilihat bahwa variabel secara parsial yang berpengaruh nyata (signifikan) terhadap permintaan telur ayam ras dikota Banda Aceh untuk strata pendapatan menengah harga telur ayam ras (X1), harga ikan (X2) dan jumlah tanggungan (X5). Dengan nilai $t_{\text {hitung }}>t_{\text {tabel, }}$, yaitu thitung harga telur ayam ras (X1) yaitu 4,453 dan tarafsignifikannya 0,00 , thitung harga ikan (X2) yaitu 2,864 dan taraf signifikan 0,006 dan thitung jumlah tanggungan (X5) yaitu 4,300 dan taraf signifikan 0,000. Sedangkan varibel lainnya yaitu harga minyak goreng (X3), dan pendapatan (X4) secara parsial tidak berpengaruh nyata terhadap permitaan telur ayam ras dikota Banda Aceh untuk strata pendapata menengah. Dimana ttabel < thitung dan taraf signifikan nya lebih besar dari 0,05

\begin{tabular}{cccc}
\hline Variabel & Harga & Nilai Elastisitas & Silang \\
\hline Harga Telur Ayam Ras (X1) & $-3,215$ & & \\
Harga Ikan (X2) & & 0,726 & \\
Harga minyak goreng (X3) & & $-0,481$ & \\
Pendapatan (X) & & $-0,047$ \\
\hline
\end{tabular}

Sumber: Data Primer, 2018 (diolah)

Dari tabel diatas dapat dilihat bahwa nilai elastisitas permintaan harga telur ayam ras di Kota Banda Aceh untuk strata pendapatan menengah adalah 3,215. Sehingga dapat disimpulkan bahwa elastisitas permintaan harga nya elastis, karena Ep > 1, akan tetapi arah nya negatif. Sedangkan nilai untuk harga ikan menunjukkan bahwa ikan menjadi barang subtitusi terhadap telur ayam ras, yaitu nilainya sama dengan positif (+) dan nilai untuk harga minyak goreng menunjukkan bahwa minyak goreng merupakan barang komplementer terhadap telur ayam ras yaitu nilainya sama dengan negaif (-). Selanjutnya untuk nilai elastisitas pendapatan juga dapat disimpulkan telur ayam ras merupakan barang inferior, karena nilai dari pendapatan lebih kecil dari 0 , dan nilai untuk strata pendapatan tinggi yaitu $-0,047<0$.

\section{Strata Pendapatan Rendah}

Pada Strata pendapatan menengah secara serempak harga telur ayam ras, harga ikan, harga minyak, pendapatan dan jumlah tanggungan mempengaruhi nyata terhadap permintaan telur ayam ras di Kota Banda Aceh, didapatkan nilai $F_{\text {hitung }} 74,404$ sedangkan $\mathrm{f}_{\text {tabel }}$ 2,57 jadi kesimpulannya diterima $\mathrm{H}_{\mathrm{a}}$.Sedangkan secara parsial yang mempengaruhi secara signifkan hanya harga telur ayam ras, harga ikan dan jumlah tanggungan yang bepengaruh secara nyata terhadap permintaan telur ayam ras di kota Banda Aceh.

Analisis Elastisitas Permintaan Konsumen Rumah Tangga Terhadap Telur Ayam Ras Di Kota Banda 61 Aceh (M. Luthfi, Mustafa, Fajri)

Jurnal Ilmiah Mahasiswa Pertanian Unsyiah, Vol.3, No.3, Agustus 2018:54-65 


\begin{tabular}{|c|c|c|c|c|c|c|}
\hline \multirow[b]{2}{*}{ Mod } & & \multicolumn{2}{|c|}{ Unstandardized Coefficients } & \multirow{2}{*}{$\begin{array}{c}\text { Standardized } \\
\text { Coefficients } \\
\text { Beta }\end{array}$} & \multirow[b]{2}{*}{$\mathrm{t}$} & \multirow[b]{2}{*}{ Sig. } \\
\hline & & B & Std. Error & & & \\
\hline 1 & (Constant) & 1.957 & 2.907 & & .673 & .507 \\
\hline & $\log \_X 1$ & -1.176 & .464 & -.279 & -2.532 & .017 \\
\hline & $\log _{-} X 2$ & .773 & .272 & .341 & 2.838 & .009 \\
\hline & $\log _{-} X 3$ & -.104 & .308 & -.018 & -.337 & .738 \\
\hline & $\log _{-} X 4$ & .141 & .143 & .060 & .983 & .334 \\
\hline & $\log _{\_} X 5$ & .599 & .139 & .427 & 4.295 & .000 \\
\hline
\end{tabular}

Sumber: Data primer, diolah 2018.

$\log \mathrm{y}=1,957-1,176 \mathrm{X}_{1}+0,773 \mathrm{X}_{2}-0,104 \mathrm{X}_{3}+0,141 \mathrm{X}_{4}+0,599 \mathrm{X}_{5}$

Nilai koefisien regresi harga telur ayam ras $\left(\mathrm{X}_{1}\right)$ sebesar $-1,176$, artinya setiap peningkatan harga telur ayam ras sebesar Rp 1/butir maka akan menurunkan permintaan telur ayam ras sebanyak 1,176 butir..Nilai koefisien regresi harga ikan $\left(\mathrm{X}_{2}\right) 0,773$ artinya setiap peningkatan harga ikan sebesar Rp 1/butir maka akan meningkatkan permintaan telur ayam ras sebanyak 0,773 butir.Nilai koefisien regresi harga minyak goreng $\left(\mathrm{X}_{3}\right)$ didapatkan nilai sebesar -0.104 , artinya setiap penambahan harga minyak goreng $\mathrm{Rp} 1 / \mathrm{Kg}$ maka akan menurunkan permintaan telur ayam ras sebesar 0,104 butir. Nilai koefisien regresi pendapatan $\left(\mathrm{X}_{4}\right)$ sebesar 0,141, artinya setiap pendapatan bertambah sebesar Rp 1 maka akan meningkatkan permintaan telur ayam ras sebanyak 0,141 butir. Nilai koefisien regresi jumlah tanggungan $\left(\mathrm{X}_{5}\right)$ adalah 0,599 artinya setiap peningkatan jumlah tanggungan 1 jiwa maka akan menaikkan permintaan telur ayam ras sebanyak 0,599 butir.

Uji t dilakukan untuk melihat pengaruh variabel independen (bebas) secara individu atau parsial terhadap variabel dependen (terikat) dengan menganggap variabel lainnya konstan. Bila $t_{\text {hitung }}>\mathrm{t}_{\text {tabel }}$ dengan signifikansi sebesar 5\% maka dapat disimpulkan bahwa secara individu variabel independen berpengaruh signifikan terhadap variabel dependen. Jika $t_{\text {hitung }}<\mathrm{t}_{\text {tabel }}$ dengan tingkat signifikansi 5\% maka dapat disimpulkan variabel independen tidak berpengaruh terhadap variabel dependen. Sementara nilai $t_{\text {tabel }}$ pada tingkat kesalahan 5\%, jumlah sampel variabel (terikat dan bebas) sebanyak 6 dan jumlah sampel 33 adalah 1,70329 dan taraf signifikan nya lebih kecil dari 0,05.Sehingga di dapatkan variabel - variabel yang berpengaruh secara signifikan yang dilihat secara parsial dan yang tidak berpengaruh signiifikan secara parsial.

Dari tabel output SPSS dapat dilihat bahwa variabel secara parsial yang berpengaruh nyata (signifikan) terhadap permintaan telur ayam ras dikota Banda Aceh untuk strata pendapatan rendah harga telur ayam ras (X1), harga ikan (X2) dan jumlah tanggungan (X5). Dengan nilai thitung > ttabel, yaitu thitung harga telur ayam ras (X1) yaitu -2,532 dan taraf signifikannya 0,017 , thitung harga ikan (X2) yaitu 2,838 dan taraf signifikan 0,009 dan thitung jumlah tanggungan (X5) yaitu 4,295 dan taraf signifikan 0,000. Sedangkan varibel lainnya yaitu harga minyak goreng (X3), dan pendapatan (X4) secara parsial tidak berpengaruh nyata terhadap permitaan telur ayam ras dikota Banda Aceh untuk strata pendapatan rendah. Dimana ttabel < thitung dan taraf signifikan nya lebih besar dari 0,05.

Analisis Elastisitas Permintaan Konsumen Rumah Tangga Terhadap Telur Ayam Ras Di Kota Banda 62 Aceh (M. Luthfi, Mustafa, Fajri)

Jurnal Ilmiah Mahasiswa Pertanian Unsyiah, Vol.3, No.3, Agustus 2018:54-65 


\begin{tabular}{lccc}
\hline Variabel & \multicolumn{3}{c}{ Nilai Elastisitas } \\
\cline { 2 - 4 } & Harga & Silang & Pendapatan \\
\hline Harga Telur Ayam Ras (X1) & $-1,176$ & & \\
Harga Ikan (X2) & & 0,773 & \\
Harga minyak goreng (X3) & & $-0,104$ & \\
Pendapatan (X4) & & 0,141 \\
\hline
\end{tabular}

Sumber: Data Primer, 2018 (diolah)

Dari tabel diatas dapat dilihat bahwa nilai elastisitas permintaan harga telur ayam ras di

Kota Banda Aceh untuk strata pendapatan rendah adalah -1,176.Sehingga dapat

disimpulkan bahwa elastisitas permintaan harga nya elastis, karena Ep > 1, akan tetapi arah nya negatif. Sedangkan nilai untuk harga ikan menunjukkan bahwa ikan menjadi barang subtitusi terhadap telur ayam ras, yaitu nilainya sama dengan positif (+) dan nilai untuk harga minyak goreng menunjukkan bahwa minyak goreng merupakan barang komplementer terhadap telur ayam ras yaitu nilainya sama dengan negaif (-).

Selanjutnya untuk nilai elastisitas pendapatan juga dapat disimpulkan telur ayam ras merupakan barang normal, karena nilai dari pendapatan $0<\mathrm{Ei}<1$, yaitu $0<0,141<1$. merupakan barang inferior, karena nilai dari pendapatan lebih kecil dari 0 , dan nilai untuk strata pendapatan tinggi yaitu $-0,047<0$.

\section{Kesimpulan}

\section{KESIMPULAN DAN SARAN}

Berdasarkan hasil dan pembahasan penelitian diatas, maka dapat ditarik kesimpulan bahwa permintaan telur ayam ras secara serempak dipengaruhi oleh harga telur ayam ras, harga ikan, harga minyak goreng, pendapatan dan jumlah tanggungan untuk keseluruhan baik strata pendapatan tinggi, menengah maupun rendah.. Jika dilihat secara parsial yang mampu mempengaruhi permintaan telur ayam ras di kota Banda Aceh secara signifikan untuk keseluruhan strata hanya lah jumlah tanggungan (X5), sedangkan harga telur ayam ras dan harga ikan mempengaruhi secara signifikan hanya unntuk strata pendapatan menengah dan pendapatan rendah.

Kemudian untuk elastisitas harga terhadap permintaan telur ayam ras dapat disimpulkan bahwa elastisitas permintaan harga nya elastis untuk strata pendapatan menengah dan strata pendapatan rendah, dimana kedua strata ini menunjukkan elastis nya kea rah yang negatif. Sedangkan untuk strata pendapatan tinggi elastisitas harga nyai nelastis. Ikan merupakan barang subtitusi dari telur ayam ras dimana pada ketiga strata tersebut nilai dari Es $>0$ atau positif (+). Minyak goreng merupakan barang komplementer dari telur ayam ras dimana pada ketiga strata tersebut didapatkan nilai Es $<0$ atau negatif (-). Selanjutnya untuk nilai elastisitas pendapatan dapat disimpulkan bahwa telur ayam ras ini merupakan barang inferior bagi konsumen rumah tangga yang ada dikota Banda Aceh, dimana koefisiesn pada strata pendapatan tinggi dan menengah menunjukkan nilai Ep < 0 , dan pada starata pendapatan rendah nilai $0<\mathrm{Ep}<1$.

\section{Saran}

Berdasarkan kesimpulan yang diperoleh, maka peneliti memberikan saran kepada pedagang telur ayam ras agar menawarkan harga yang murah kepada konsumen, karena jika harga nya tinggi maka akan mengurangi permintaan telur ayam ras di kota Banda

$\overline{\text { Analisis Elastisitas Permintaan Konsumen Rumah Tangga Terhadap Telur Ayam Ras Di Kota Banda }} 63$ Aceh (M. Luthfi, Mustafa, Fajri)

Jurnal Ilmiah Mahasiswa Pertanian Unsyiah, Vol.3, No.3, Agustus 2018:54-65 
Aceh dimana konsumen berpendapatan menengah dan rendah sangat memperhitungkan harga dari telur ayam ras.

Kemudian juga disarankan kepada pedagang untuk meyediakan telur ayam ras jika terjadi nya kenaikan pada harga ikan, karena hal ini akan sangat meningkatkan permintaan telur ayam ras melihat ikan merupakan barang subtitusi untuk telur ayam ras dan elastisitas harga nya elastis baik untuk strata pendapatn menengah dan strata pendapatan rendah.

\section{DAFTAR PUSTAKA}

Agus, S. 2005. Manajemen Kearsipan Modern. Gava Media. Jakarta.

Agus, S. 2006. Teori dan Paradigma Penelitian Sosial. Tiara Wacana. Yogyakarta.

Arikunto, S. 2013. Prosedur Penelitian Suatu Pendekatan Praktik. Rineka Cipta. Jakarta.

Bayu, P. 2014. Manejemen Pemasaran. Dimar Intermedika. Kediri.

Daniel, M. 2002. Pengantar Ekonomi Pertanian. Bumi Aksara. Jakarta.

Dian, D. 2016. Analisis Faktor-Faktor yang Mempengaruhi Permintaan Daging Sapi di Kota Surakarta. Jurnal Agrista. 4: 94 - 103.

Fachrul, I, H 2014. Analisis Faktor - Faktor yang Mempengaruhi Permintaan Tempe di Kelurahan Jurangmangu Timur, Tangerang selatan. Jurnal Agribisnis. $8: 45-$ 58. (1).

Fatmawati. 2016. Faktor-Faktor yang Mempengaruhi Permintaan Daging Sapi di Indonesia. Jurnal Ekonomi. $1: 128$ - 134. (1).

Firdaus, M. 2008. Manajemen Agribisnis. Bumi Aksara. Jakarta.

Handewi, P. 2002. Analisis Permintaan Pangan di Kawasan Timur Indonesia.Jurnal Agro Ekonomi. 20. 64 - 91. (2).

Haromain, I. 2010. Faktor- Faktor yang Mempengaruhi Permintaan Daging Sapi di Indonesia Pada Tahun 2000-2009. Program Studi Agribisnis. Fakultas Sains dan Teknologi. Universitas Islam Syarif Hidayatullah. Jakarta.

Haryadi, N. 2013. Kambing Perah. Arcita. Solo.

Ismiyati, F .2003. Kepemilikan Manajeria, Kepemilikan Institusional, Risiko, Kebijakan Hutang, dan Kebijakan Deviden Analisis Persamaan Stimulan. Simposium Jurnal Akuntansi.

Kerlinger. 2006. Metode Penelitian Pendidikan. Alfabeta. Bandung.

Murtala. 2011. Analisis Permintaan Minyak Goreng di Kota Banda Aceh. Jurnal Aplikasi Manajemen. 9 : 264 -270. (1).

Analisis Elastisitas Permintaan Konsumen Rumah Tangga Terhadap Telur Ayam Ras Di Kota Banda 64 Aceh (M. Luthfi, Mustafa, Fajri)

Jurnal Ilmiah Mahasiswa Pertanian Unsyiah, Vol.3, No.3, Agustus 2018:54-65 
Mujiyanto. 2001. Analisis Permintaan Daging Sapi di Kota Manokwari. Universitas Cendrawasih. Manokwari.

Nana, S. 2010. Dasar-Dasar Proses Belajar. Sinar Baru. Bandung.

Pracoyo, A. 2006. Aspek Dasar Ekonomi Mikro. PT. Gramedia Widiasarana. Jakarta.

Analisis Elastisitas Permintaan Konsumen Rumah Tangga Terhadap Telur Ayam Ras Di Kota Banda 65 Aceh (M. Luthfi, Mustafa, Fajri)

Jurnal Ilmiah Mahasiswa Pertanian Unsyiah, Vol.3, No.3, Agustus 2018:54-65 